\title{
First record of Myrmica salina Ruzsky (Hymenoptera: Formicidae) for Poland
}

\author{
Alexander RADCHENKO*, Anna STANKIEWICZ* and Marcin SiELEZNIEW** \\ *Laboratory of Social and Myrmecophilous Insects, Museum and Institute of Zoology, Polish Academy of Sciences, \\ Wilcza 64, PL-00-679 Warszawa, Poland; e-mail: agradchenko@hotmail.com \\ **Department of Applied Entomology, Warsaw, Agriculture University, Nowoursynowska 166, 02-787, Warszawa, \\ Poland; e-mail: sielezniew@alpha.sggw.waw.pl;
}

Abstract: A rare and little known ant species, Myrmica salina Ruzsky is for the first time reported from Poland. General data on its distribution and ecology are given. Characteristic morphological features of the species are pointed out and compared with those of closely related species.

Key words: ants, Myrmica salina, scabrinodis-group, morphology, fauna of Poland

\section{INTRODUCTION}

The fresh monograph "The ants of Poland" published by Czechowski et al. (2002) includes 15 Myrmica species. Recently further two species of this genus were discovered in Poland (Radchenko et al. 2003). In 2003 two of the co-authors of this paper (A. Stankiewicz and M. Sielezniew) found during field studies one more species, new for the Polish fauna - M. salina Ruzsky. Therefore, if we take in account synonymization of the generic name Symbiomyrma Arnoldi with Myrmica Latreille (Radchenko \& Elmes 2003), at the moment 18 Myrmica species are known from Poland.

\section{METHODS}

A wide range of morphometric indices are used for the identification of Myrmica species (for details see Radchenko and Elmes 1998, 1999). The following measurements were used for the discrimination:

HW - maximum width of head in dorsal view behind the eyes;

$\mathrm{HL}$ - length of head in dorsal view, measured in a straight line from the anterior point of median clypeal margin to mid-point of the occipital margin;

SL - maximum straight-line length of antennal scape seen in profile;

$\mathrm{FW}$ - minimum width of frons between frontal lobes;

$\mathrm{FI}=\mathrm{FW} / \mathrm{HW}$;

$\mathrm{SI}=\mathrm{SL} / \mathrm{HL}$.

\section{TAXONOMIC NOTES}

Myrmica salina was described by Ruzsky (1905) from workers, queens and males from southern part of West Siberia and Northern Kazakhstan as a variety of M. scabrinodis Nylander. Arnoldi (1970) raised this form to the species rank and considered it as a species different from M. slovaca Sadil, Seifert (1988) however considered M. slovaca as a junior synonym of M. salina. Radchenko (1994a, b) proposed another treatment of M. salina (sensu Ruzsky, not sensu Arnoldi and Seifert) and considered it as a junior synonym of M. lacustris 
Ruzsky (= M. deplanata Ruzsky); correspondingly $M$. salina sensu Arnoldi and Seifert was considered as synonym of $M$. slovaca. These strong disagreements of treating of $M$. salina were based first of all on the absence of the types of $M$. salina and on not completely clear original Ruzsky's description of this species. At last Seifert (2002) revived M. salina from synonymy, again considered it as senior synonym of $M$. slovaca, and proposed to fix the neotype of $M$. salina (the worker from Novosibirsk Region, erroneously designated by Arnoldi (1970) as the lectotype). We now accept the last Seifert's last treatment of this species.
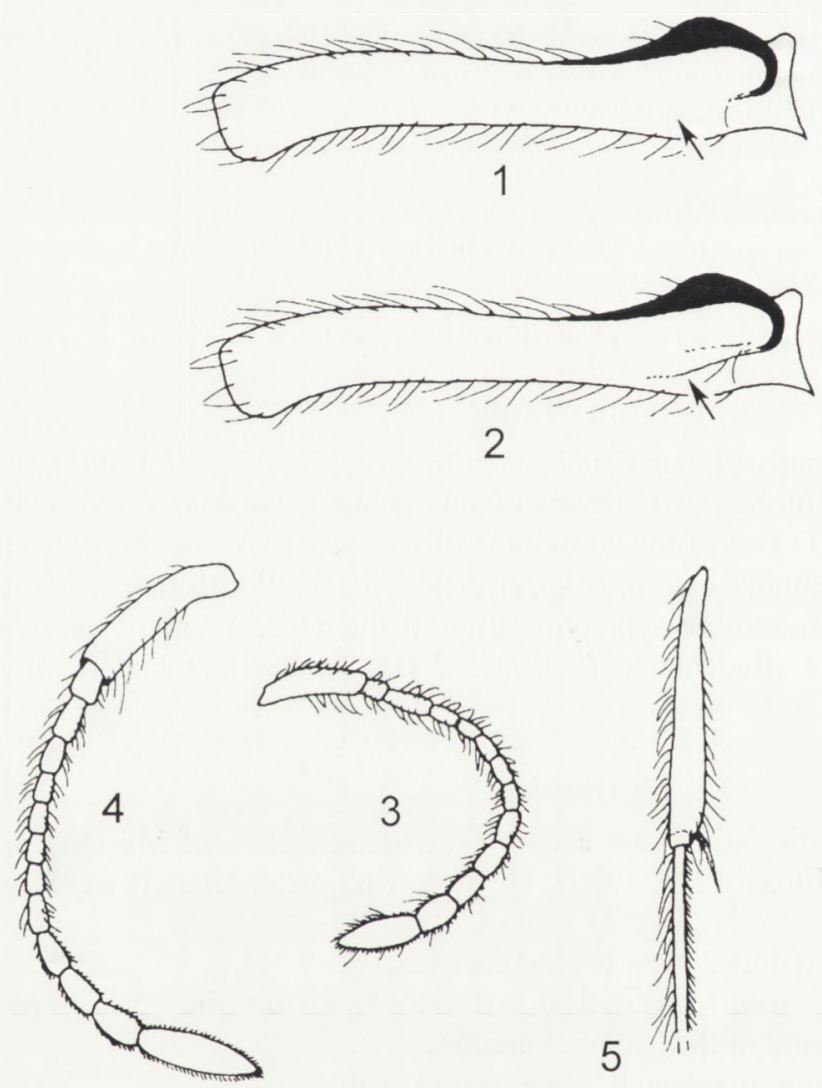

Figs 1-6. Details of structure of Myrmica species; 1, 2 - antennal scapes (workers, dorsal view): 1 - M. salna; 2 - M. sabuleti, lectotype; 3, 4 - antennae (males): 3-M. salina, 4-M. sabuleti, paralectotype; 5, 6 - tibiae and first tarsal joint (males): 5-M. salina, 6-M. tulinae.

Among all Polish species of Myrmica, workers and queens of $M$. salina the most resemble M. sabuleti Meinert and M. tulinae Elmes et al. and they could be confused only with them. On the other hand, $M$. salina quite well differs from the latter species by several features, the most important among them are:

- frons distinctly narrower ( $\mathrm{FI}<0.30$, mean 0.27 versus $\mathrm{FI}>0.30$, mean $0.33-0.34$ respectively);

- lobe at the base of antennal scape does not continue to the longitudinal carina on the dorsal surface of scape (in $M$. sabuleti and $M$. tulinae this lobe continues to the longitudinal carina, compare Figs 1 \& 2). 
Males of all three considered species differ much better than their female castes. First of all, males of $M$. salina and $M$. tulinae have much shorter antennal scape than those of $M$. sabuleti (CI $<0.45$ versus $>0.50$, compare Figs $3 \& 4)$, and $M$. salina well differs from $M$. tulinae by much shorter standing hairs on the tibiae and tarsi (compare Figs $5 \& 6$ ). On the other hand, males of $M$. salina are practically indistinguishable from those of $M$. specioides Bondroit, $M$. hellenica Forel and M. rugulosa Nylander.

\section{DISTRIBUTION AND ECOLOGY}

M. salina is a widespread species and occuring over a large area: from Altai Mts to Switzerland and from Bulgaria, Serbia, Turkey and Georgia to southern Byelorussia and Riazan' Region of Russia. It prefers habitats with quite high salinity (especially in the eastern part of the range), however it also inhabits xerothermous grasslands.

In Poland M. salina was discovered at Krówniki (4947’ N/22 $51^{\prime} \mathrm{E}, 200 \mathrm{~m}$ a.s.l.) near Przemyśl in SE part of the country, close to Ukrainian border. The site encompassed open grasslands with calcareous soil substrate. Diverse vegetation structure can be classified as transitional between Molinietum medioeuropaeum and Arrhenatheretum medioeuropaeum associations. Most of the meadow was covered by tall and dense grasses and herbs like Sanguisorba officinalis, Gallium sp., Centaurea sp. The site was apparently regularly mowed at least one time per year.

M. salina inhabited patches of ground with the lowest and thin vegetation. Nests were built in bare ground without mounds and included no more than a few hundreds of workers. First samples of the workers from two nests were collected in mid June 2003. Further specimens, including males and queens, were obtained from three colonies in the late July 2003. M. salina shared habitat with M. scabrinodis, M. rubra (Linnaeus), Lasius niger (Linnaeus) and L. flavus (Fabricius). In the patches of the meadow where $M$. salina was recorded, $M$. scabrinodis was the most common Myrmica species. M. rubra inhabited places with higher vegetation where $M$. salina was absent.

\section{REFERENCES}

ARNold K. V. 1970. A review of the genus Myrmica (Hymenoptera, Formicidae) of the European part of the U.S.S.R. Zool. Zh. 49 (12): 1829-1843 (in Russian).

Czechowski W., Radchenko A. G. \& Czechowska W. 2002. The ants (Hymenoptera, Formicidae) of Poland. Museum and Institute of Zoology PAS, Warszawa, $200+1$ pp.

RADCHENKO A. G. 1994a. A review of species the scabrinodis-group of the genus Myrmica LATREILLE (Hymenoptera, Formicidae) of the Central and Eastern Palaearctic. Zool. Zh. 73: 75-82 [in Russian; English translation: Entomol. Rev. 74 (1995): 116-124].

RADCHENKO A. G. 1994b. A review of of species the rubra, rugosa, arnoldii, luteola and schencki-groups of the genus Myrmica Latreille (Hymenoptera, Formicidae) of the Central and Eastern Palaearctic. Zool. Zh. 73: 122-132 [in Russian, English translation: Entomol. Rev. (1995 b) 74: 122-132].

RAdChenko A. G. \& Elmes G. W. 1998. Taxonomic revision of the ritae species-group of the genus $M y r m i c a$ (Hymenoptera, Formicidae). Vest. Zool. 32: 3-27.

Radchenko A. G. \& Elmes G. W. 1999. Ten new species of Myrmica (Hymenoptera, Formicidae) from the Himalaya. Vest. Zool. 33: 27-46.

RAdChenko A. G. \& Elmes G. W. 2003. A taxonomic revision of the socially parasitic Myrmica ants (Hymenoptera, Formicidae) of Palaearctic Region. Annales Zoologici 53: 217-243.

Radchenko A. G. Elmes G. W., Czechowska W., Stankiewicz A., Czechowski W. \& Sielezniew M. 2003. First records of Myrmica vandeli BONDROIT and $M$. tulinae ELmES, RADCHENKO et AKTAÇ (Hymenoptera: Formicidae) for Poland, with a key for the scabrinodis- and sabuleti-complexes. Fragm. faun. 46: 47-57.

RuZSKY M. D. 1905. The ants of Russia (Formicariae Imperii Rossici). Trudy obschtsch. est. Imp. Kazan Univ. $38:$ 1-799.

SEIFERT B. 1988. A taxonomic revision of the Myrmica species of Europe, Asia Minor, and Caucasia (Hymenoptera, Formicidae). Abh. Ber. Naturkundemus. Görlitz. 62: 1-75.

SEIFERT B. 2002. The "type" of Myrmica bessarabica NASONOV 1889 and the identity of Myrmica salina RUZSKY 1905 (Hymenoptera, Formicidae, Myrmicinae). Mitt. Münch. Ent. Ges. 92: 93-100. 


\section{STRESZCZENIE}

[Pierwsze doniesienie o występowaniu Myrmica salina RUZSKY (Hymenoptera: Formicidae) w Polsce]

W niniejszej pracy zawarte jest pierwsze doniesienie o występowaniu w Polsce nowego dla krajowej myrmekofauny gatunku mrówki, Myrmica salina, wraz z informacjami o jego rozmieszczeniu geograficznym, ekologii, cechach morfologicznych i statusie taksonomicznym tego gatunku. M. salina została znaleziona w 2003 r. w Krównikach k. Przemyśla (leg. Stankiewicz and Sielezniew). Łącznie znaleziono 5 kolonii na nawapiennej łące kośnej noszącej cechy pośrednie zbiorowisk Molinietum medioeuropaeum i Arrhenatheretum medioeuropaeum. M. salina jest 101 gatunkiem mrówki w Polsce. 